\title{
Early stages of snapper-grouper exploitation in the Caribbean (Bay Islands, Honduras)
}

\author{
Bertrand Gobert $^{\mathrm{a}, *}$, Patrick Berthou ${ }^{\mathrm{b}}$, Ester Lopez ${ }^{\mathrm{c}}$, Patrick Lespagnol ${ }^{\mathrm{d}}$, Maria Dolores Oqueli Turcios ${ }^{\mathrm{e}}$, \\ Christophe Macabiau ${ }^{f}$ and Pedro Portillo ${ }^{g}$
}

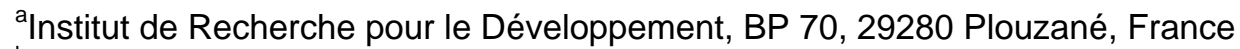 \\ ${ }^{\mathrm{b}}$ Institut Français de Recherche pour l'Exploitation de la Mer, BP 70, 29280 Plouzané, France \\ ${ }^{\mathrm{C} C}$ Colonia Altamira, Casa 1564, Boulevard Suyapa, Tegucigalpa, Honduras \\ 'Institut Français de Recherche pour l'Exploitation de la Mer, BP 171, 34203 Sète Cedex, France \\ 29, rue Egalité, 75019 Paris, France \\ 'PolySpace Technologies, 28, Rue Estienne d'Orves, 92120 Montrouge, France \\ 'Université des Antilles et de la Guyane, BP 592, 97159 Pointe-a-Pitre Cedex, France
}

*: Corresponding author : Tel : (33) 298224516 ; Fax : (33) 298224514 ; gobert@ird.fr

\begin{abstract}
:
In the Caribbean, snappers (Lutjanidae) and groupers (Serranidae) are often heavily exploited by artisanal or industrial fisheries. This paper analyzes the catches of an artisanal fishery selectively targeting these species with a moderate fishing pressure in the Bay Islands (Honduras), and discusses the implications on the understanding of the early stages of development of reef fisheries. Although snappers and groupers are targeted with handlines and spearguns in the whole archipelago, the differences in species diversity and size structure of the catch reveals various exploitation patterns. In most areas, a depletion is observed for the most vulnerable snapper and grouper species, and most other species are mainly exploited in their juvenile phase; clear signs of an intensification process are apparent in one of the areas. The comparison of the relative production in the Bay Islands with other reef fisheries in the Caribbean suggests that higher values may be related to moderate fishing pressure and appropriate combinations of fishing effort and selectivity. This example shows how fisheries strictly targeting a high quality resource with selective fishing techniques can be quite productive even at high levels of effort, but also that they are progressively lead to broaden their species range (sooner or later at the expense of the most vulnerable, often large-sized, species) while increasingly using less selective gears.
\end{abstract}

Keywords: Snappers; Groupers; Reef fisheries; Artisanal fisheries; Caribbean; Selective fishing effort; Top-level predators 


\section{Introduction}

Lutjanidae and Serranidae, sometimes considered jointly as a "snapper-grouper complex" (Coleman et al., 1999), are keystone species in coral reef ecosystems (Parrish, 1987) and major resources for tropical fisheries. In the Caribbean, they are exploited (a) by industrial or semi-industrial line fisheries targeting a few species for local or export markets (Claro et al., 2001 ; Contreras et al., 1996 ; Mendoza and Larez, 1996), (b) by small-scale fisheries intensively exploiting the whole reef fish community with non-selective gears like traps or nets (Gobert, 2000 ; Kimmel and Appeldoorn, 1992 ; Luckhurst, 1996 ; Matos-Caraballo, 1997 ; Munro, 1983), and (c) by small-scale fisheries directed on them with moderate or low fishing pressure, being both selective (handlines) and much less active than export-oriented conch or lobster fisheries. Unlike the first two categories, little is known about this latter form of exploitation, in spite of a few published studies (e.g. Auil et al., 1999 ; Koslow et al., 1994 ; Smith, 1988). This paper presents an analysis of such a fishery located on the Caribbean coast of Honduras.

The Bay Islands archipelago is made of three main islands extending over $130 \mathrm{~km}$, about 50 $\mathrm{km}$ from the continent (Fig. 1). Whereas Utila lies on the continental shelf, Roatán and Guanaja are the emerged parts of two submarine platforms separated by depths greater then $400 \mathrm{~m}$. Coral reefs are found all around the islands, but lagoons are narrow and the development of true barrier reefs is limited by the steepness of outer slopes. The archipelago has a population of about 48000 people whose main activity is fishing. A fleet of 334 semi-industrial boats (in 1998) is based in Roatán but fishes exclusively on the eastern part of the Honduran EEZ, without interacting with the artisanal fleets of the Bay Islands. There has never been any significant public policy of fishery development (loans, subsidies, infrastructures) or management (boat registration, catch or effort limitations) for the Bay Islands local fishery, which was unregulated so far.

\section{Materials and methods}

As part of an integrated coastal management project (Proyecto Manejo Ambiental de las Islas de la Bahía), a two-year monitoring and sampling protocol was applied on the landing sites in 1999 and 2000 (Berthou et al., 2001). Data collection included an initial frame survey (identification of fishermen communities, fleet census) and a 2-year monitoring phase. The monitoring was based on a monthly census of active boats, a daily record of effort, gear and catch over a sample of boats in the most active fishing communities (Table 1), and detailed catch observations (species identification, length and/or weight measurements, biological sampling) on randomly selected boats (Table 2). The sampling was stratified according to area (cf. below), fishing gear and engine power $(0,<20 \mathrm{hp}, \geq 20$ hp). The amount of data was quite important but sampling rates differed between the islands according to the personnel available : whereas Utila was intensively sampled, Santa Elena and West Roatán were rather under-sampled.

Results are presented for 1999 only except for catch length structure, for which data of both years were pooled to compensate for the small sizes of area/gear/species samples. Fish were measured in centimetres of fork length (snappers) or total length (groupers). Fishing effort of all gears were standardized according to cpue and expressed in hook-hour.

Owing to its size and the previous knowledge of the fishery, the island of Roatán was divided in three areas (Fig. 1). Shelf areas were computed by a Geographical Information System, except for Utila which has no shelf of its own.

When possible, species-based analyses were conducted as a contribution to the understanding of the whole multispecific fishery. Values of the growth parameters $\mathrm{K}$ and $\mathrm{L}_{\infty}$ and of the size at first reproduction were chosen as the most reliable ones provided by the literature (Claro et al., 2001 ; Manooch, 1987) (Table 3). Natural mortality was estimated from K with the empirical relation established for tropical snappers and groupers (Ralston, 1987). When samples and available growth parameters were considered reliable, total mortality was estimated with length-converted catch curve using FISAT (Gayanilo et al., 1996), and/or exploitation regimes were studied with length pseudocohort analysis and yield-per-recruit simulation using ANALEN (Chevaillier and Laurec, 1990). 


\section{Results}

\subsection{The exploitation of snappers and groupers}

The 518 small-scale boats of the archipelago range from unmotorized dugout canoes to fiberglass boats with outboard or diesel engine, and go fishing only for a few hours. They are larger, more often and more powerfully motorized in Utila than in the other areas, especially East Roatán and Santa Elena (Table 4). Most boats of Utila operate on a wide area of the continental shelf between Punta Sal and Puerto Castilla (Fig. 1), whereas those of Roatán and Guanaja fish almost exclusively on the nearby shelves and reef slopes. As a consequence, there is very little spatial interaction between fleets of the different areas.

Fishing uses mainly bottom lines and various underwater techniques like collecting queen conch, hooking lobsters, and spearing fishes (Table 5). A small part of the handline fishery targets deep snappers. Overall landings amounted to 675 tons in 1999, dominated by demersal fishes $(538 \mathrm{t})$; snappers and groupers ( $421 \mathrm{t}$ ) account together for 50.9 to $88.3 \%$ of the demersal fish catch according to the area (Fig. 2). In East Roatán, Scaridae, Haemulidae, Carangidae and Balistidae are other important components of the catch (more than $5 \%$ each). Lines are almost the only gear used to catch shallow-water snappers, except in East Roatán (38 \% by spearguns). Groupers are caught mainly with lines in Utila and West Roatán, but spearguns are important (38 \%) in Santa Elena and dominant (more than $60 \%$ ) in East Roatán and Guanaja (Fig. 3).

Fishing effort for reef species, and snapper-grouper catches, vary widely between islands (Table 6). The relative effort varies by a factor of 7 between Guanaja and East Roatán, and the relative catch by a factor of 8 to 10 between Santa Elena and West Roatán where the catch is the highest (1.6 $\mathrm{t} / \mathrm{km}^{2}$ ). West and East Roatán are the most intensively exploited areas but their average cpue have respectively a high value and the lowest one. Unlike the catch, the fishing effort cannot be partitioned between shallow and deep species : the cpue for shallow species is therefore somewhat overestimated since part of the effort is directed towards deep snappers.

\subsection{Species composition of snapper and grouper catches}

Nine species of shallow-water snappers (Ocyurus chrysurus, Lutjanus analis, L. synagris, $L$. apodus, L. jocu, L. griseus, L. purpureus, L. cyanopterus, L. mahogoni) were identified (Fig. 4). O. chrysurus is found in significant proportions in all areas, especially in Utila and West Roatán where the snapper catch is almost monospecific. In the other areas, the bulk of the catch is made of several species ( 2 in Guanaja, 4 in Santa Elena, and 5 in East Roatán), with a correspondingly smaller share of the main one, respectively $45.7 \%$ (L. synagris), $24.7 \%$ (L. synagris), and $27.9 \%$ (L. apodus).

Thirteen species of groupers (Dermatolepis inermis, Epinephelus adscensionis, E. cruentatus, E. flavolimbatus, E. fulvus, E., guttatus, E. itajara, E. striatus, Mycteroperca bonaci, M. interstitialis, M. phenax, M. tigris, M. venenosa) were recorded (Fig. 5). As with snappers, the catch is dominated by a single species in Utila and West Roatán (but to a lesser extent : 56.3 and $63.2 \%$ respectively), and is more evenly shared in Santa Elena ( 3 species, from 34.4 to $22 \%$ ) and East Roatán (6 species, from 20.3 to $12.4 \%$ ). E. cruentatus dominates in West Roatán, but there is no general pattern of respective importance between large and small groupers. No single species is found in significant proportions in the catch of all areas.

\subsection{Size structure of snapper and grouper catches}

Recruitment into the catch generally occurs between 15 to $20 \mathrm{~cm}$ (Fig. 6), and in most cases the largest length is close to the maximum size known for the species; this is particularly true for the smallest species (L. synagris, E. fulvus, E. cruentatus) but much less so for some of the largest ones (O. chrysurus, E. striatus). Although the sample distribution of survey data did not allow an ANOVA (species, area, gear), the histograms show that area, and not fishing gear, is the dominant factor of variability for a given species (Fig. 6). The fish landed in Utila tend to be larger, and those landed in East Roatán smaller, than elsewhere, with length differences sometimes exceeding $15 \mathrm{~cm}$ (Table 7). Utila is involved in 33 of the 48 highly significant differences, with larger mean sizes in $97.3 \%$ of the cases (Table 8) ; conversely, East Roatán is involved in 10 of the remaining 15 highly significant differences, but very rarely with larger mean sizes ( $8.6 \%$ of the comparisons).

\subsection{Species-specific indicators of fishing pressure}

Despite limitations of biological knowledge and field data, the length structure of catch provides valuable information on the fishing pressure exerted on snapper and grouper populations. 
O. chrysurus is caught mainly as adults, except in East Roatán and Guanaja ; in Utila the present exploitation regime is close to the optimum of biological production, but the very early selection in East Roatán leads to growth overfishing in spite of a lower fishing mortality.

The exploitation of L. analis shows two differents aspects. In Utila, the highly seasonal fishery (Fig. 7) is related to a mass migration of fish, observed each year by fishermen to move in dense groups along the Hondurian shelf edge. In Roatán and Guanaja, landings are spread more evenly around the year, suggesting the exploitation of local populations isolated by deep waters from this migration. Juveniles predominate in all areas, especially in East Roatán where the steep recruitment at low sizes makes growth (and possibly recruitment) overfishing likely for this large species.

In Guanaja and Santa Elena, the exploitation rate of $L$. synagris is high and only marginal production increases could be expected from changes in the exploitation pattern. In contrast, the exploitation rate is much lower in Utila where the stock is somewhat under-exploited.

E. striatus is caught mainly as adults in Utila, and as juveniles in the other areas (even early juveniles in East Roatán). In Utila, the catch of predominantly large fish in February could mean that the fishery exploits a spawning aggregation. Such an aggregation was discovered in Guanaja in 1988, with catch peaking in Dec. 90- Jan. 91 (at least $30 \mathrm{t}$ ) before declining strongly in January 1992 (Fine 1990, 1992). The very low landings of $1999(0.2 t)$ and $2000(0.3 t)$ in Guanaja strongly suggest that the aggregation has now been fished out.

In East Roatán M. venenosa is fished mainly as juveniles ; in Utila, the fishing pressure is very low, as indicated by a low exploitation rate applied to only the largest individuals.

Catches of E. fulvus and E. guttatus are mainly made of adults in all islands, with a higher proportion of immatures in East Roatán, Santa Elena and Guanaja. Estimates of exploitation rates suggest that E. fulvus supports a much higher fishing pressure than E. guttatus, with lower values in Utila than in the other areas for both species.

\subsection{Comparison between areas}

Snappers and groupers are the only target of the finfish fisheries of the Bay Islands, and the other families can be viewed as by-catch only. Within this general framework, two main exploitation patterns are observed. In Utila, a powerful artisanal fleet fishes on a variety of banks to supply an export market with high-valued fishes. Only a few snapper species are actively sought with handlines, and the moderate fishing pressure allows the selective catch of quite large fish. In Roatán and Guanaja, largely non-mechanized fleets fish close to shore on island shelves, using handlines and spearguns to catch a wide variety of snappers and groupers for local markets or self-consumption; fishing pressure is high because of small selection sizes, but also (at least in some cases) high fishing mortality.

Widely different situations are found in the latter two islands (Table 6). In Santa Elena and especially in Guanaja, the fishery is moderately intensive ; the cpue is only moderate because the level of effort is not high enough to compensate for the small size of fish. In East Roatán, all signs of an intensification process can be seen : very high relative effort, low species selectivity in all fish families, low recruitment sizes. The cpue is the lowest of all areas but the high level of effort still yields a moderate relative catch. Growth overfishing is demonstrated or likely in several cases. In West Roatán, fishing effort is also high but very selective (handlines only) ; targeting large snappers with high selection sizes allows the values of both relative catch and cpue to be the highest of the two insular shelves.

\section{Discussion}

The characteristics of the Bay Islands fishery are typical of "targeted" reef fisheries (selective gears, large and high-valued predatory target species, low or moderate fishing pressure, limited impact on habitat and fish community), as opposed to "opportunistic" ones (low gear selectivity, highly diversified catch, high fishing pressure or overexploitation, strong ecological impact). Most reef fisheries fall between these two types, and reef fish communities can be classified in a similar way according to fishing pressure (Russ, 1991). The Bay Islands fishery is not new, with yields lower than those reported on virgin or underexploited areas of the Honduras-Nicaragua shelf (Kawaguchi, 1974), but it is to some extent representative of early stages of reef fisheries, as shown by the discussion of the hypotheses which could explain the catch differences observed between areas.

Located a few tens of kilometers apart, the reefs of the three islands show little reason for being very different ecosystems, and probably had comparable fish communities before any fishing 
took place. Likely factors of ecological difference between Utila and the other two islands are its position on the continental shelf and the distance of reefs from land, but could not account for the size structure of snapper-grouper catches.

There is no reason to question the technical ability of the line fishing fleets of Guanaja and especially Roatán to selectively target large snapper/grouper fish and/or species as is done in Utila with the same gear. The supply of hooks of the appropriate size and shape to catch large fish has certainly never been a serious limiting factor, and the narrowness of the insular shelves makes all habitats quite accessible, even to non-powered boats. If they could fish on the grounds exploited by the fishermen of Utila, those of Roatán and Guanaja would obtain similar results in terms of species composition of catch. The catch differences between islands thus reflects more the state of the stocks than the fishing technology applied on them.

At least in some parts of Roatán and Guanaja (particularly in East Roatán), an obvious depletion is observed for some of the largest species (O. chrysurus, L. analis, E. striatus), and most species are mainly exploited in their juvenile phase. When applicable, the yield-per-recruit analysis confirms that early selection size, often more than fishing mortality, is detrimental to the catch. As expected, the impact of fishing is lower for the smaller species (L. synagris, E. fulvus, E. guttatus, E. adscensionis, E. cruentatus) which are always caught mainly with handlines. Large grouper species (E. striatus, Mycteroperca spp, etc) are caught in all areas but with different techniques : whereas they are predominantly caught with lines in Utila, the smaller individuals are caught elsewhere in larger proportions with spearguns, nets, and sometimes traps. The vulnerability of species to the fishery is thus dependent on their size, but behaviour can also be an important factor, as shown by the extinction of the Nassau grouper spawning aggregation in Guanaja.

Most of the observed catch differences are thus probably attributable to fishing patterns. From an initial situation where fishermen can afford targeting only the few most rewarding and abundant species with a moderate fishing pressure (which is still possible in Utila because of a wide fishing area and little competition from other fleets), the narrow operating range of fishermen in Roatán and Guanaja lead them to increase the fishing pressure on local stocks. This resulted in the more intensive exploitation (and in some cases the overfishing) of the large or vulnerable species initially targeted, the shift in target of the handlines from large to small species, and the subsequent introduction of less selective gears. The situation in East Roatán can be seen as marking a decisive step in this intensification process.

However, even in the heavily exploited areas, the most vulnerable species (by their size or their behaviour) are still present in the catches, while the smallest groupers of commercial interest (like creole fish Paranthias furcifer or mutton hamlet Alphestes afer) are not yet targeted or even landed as by-catch, as opposed to many Caribbean fisheries, like Bermuda (Luckhurst, 1996), or Martinique (Gobert, 1991, 1996 ; Reynal et al., in press).

The question of how much fish can be caught in reef areas (Marten and Polovina, 1982 ; Munro, 1984 ; Neilson et al., 1999) is of particular relevance for top-level predators in the context of increasing fishing pressure. The relative annual production of shallow-water snappers and groupers in the Bay Islands was found to vary widely, from $0.15-0.20 \mathrm{t} / \mathrm{km}^{2}$ in Guanaja and Santa Elena to more than $1.40 \mathrm{t} / \mathrm{km}^{2}$ in West Roatán (Table 6). Relative yield comparison between fisheries is not straightforward (Dalzell, 1996), but these ranges can be compared to the estimations of $0.23 \mathrm{t} / \mathrm{km}^{2}$ in Martinique (Gobert, 1990), and 0.31 and $0.14 \mathrm{t} / \mathrm{km}^{2}$ respectively in Belize and in Jamaica (Koslow et al., 1994). On the Bahamas banks, maximum yields were estimated in the range $0.14-0.41 \mathrm{t} / \mathrm{km}^{2}$ (Smith, 1988). The values obtained in the Bay Islands are thus either comparable (in Guanaja and Santa Elena) or much higher (in West Roatán). The relative production of this latter area may seem excessively high; the low sampling rate could possibly have entailed an overestimation of the production, but not to such an extent as to completely explain the difference with the other areas. This much higher value can be interpreted in the light of the exploitation patterns. In Belize and Bahamas, fishing is mostly directed towards conch and lobster and the snapper-grouper resource is subject to a very low and selective fishing pressure. In Jamaica and Martinique, the whole reef fish resource is intensively exploited with non-selective gears like traps, gillnets and trammelnets, with only 20 to 25 $\%$ of snappers and groupers in the catch. In these two exploitation patterns (but for opposite reasons), the relative production of these species is low. In contrast, the fishing patterns found in Roatán present 
combinations of fishing effort and selectivity which are quite different but allow the production to be at high or moderate levels.

\section{Conclusion}

Early or intermediate stages of snapper-grouper exploitation had not been described and analysed so far with detailed catch and effort data. The example of the Bay Islands shows how fisheries strictly targeting a high quality resource with selective fishing techniques can be quite productive even at high levels of effort, but also that they are progressively lead to broaden their species range (sooner or later at the expense of the most vulnerable, often large-sized, species) while increasingly using less selective gears. This shift in exploitation pattern can be compatible with the targeted exploitation of snappers and groupers as long as the economic return from these groups is sufficient for the livelihood of fishermen. But if fishing pressure keeps increasing, the decline in yield of snappers and groupers will make necessary to broaden the species spectrum of the catch to other fish families, and the fishery will then belong to the highly multispecific, opportunistic type now found in many Caribbean countries and islands.

\section{Acknowledgements}

This study is based on data collected within the fisheries component of the "Proyecto de Manejo Ambiental de las Islas de la Bahía" (PMAIB) funded by the Inter-American Development Bank and run by SAFEGE. The authors are grateful to Mr. Jacques Grelot (Director of the project), to Mr. Enoc Burgos (Leader of the Coordination Unit of the sub-program "Natural Resources"), to Mrs. Isabelle Valade and to all the people who facilited the collection and the processing of the data.

\section{References}

Auil, S.A., Aiken, K.A. , Koslow, J.A., 1999. An assessment of the Belize coral reef fishery. Proc. Gulf Carib. Fish. Inst. 45, 84-94.

Berthou, P., Oqueli, M. D., Lopez, E., Gobert, B., Macabiau, C., Lespagnol, P., 2001. Diagnostico de la pesca artesanal de las Islas de la Bahía. Proyecto Manejo Ambiental de las Islas de la Bahía, Informe tecnico PES 06, 195.

Chevaillier, P., Laurec, A., 1990. Logiciel pour l'évaluation des stocks de poisson ; Analen : Logiciel d'analyse des données de capture par classes de taille et de simulation des pêcheries multi-engins avec analyse de sensibilité. FAO Fish. tech. Paper. 101 (suppl. 4), 124.

Claro, R., Lindeman, K.C., Parenti, L.R., 2001. Ecology of the marine fishes of Cuba. Smithsonian Acad. Press, Washington-London, 253.

Coleman, F.C., Koenig, C.C., Eklund, A.M., Grimes, C.B., 1999. Management and conservation of temperate reef fishes in the snapper-grouper complex of the Southeastern United States. Am. Fish. Soc. Symp. 23, 233-242.

Contreras, M., Moreno, V., Burgos, R., Valdes, R., 1996. Population dynamics and stock assessment of red grouper (Epinephelus morio) fishery on Campeche Bank, Mexico. ICLARM Conf. Proc. 48, 202-217.

Dalzell, P., 1996. Catch rates, selectivity and yields of reef fishing. In: Polunin N.V.C., Roberts C.M. (Eds), Reef fisheries. Chapman \& Hall, London, pp. 161-192.

Fine, J.C., 1990. Groupers in love. Sea Frontiers, Jan-Feb. 1990, 42-45.

Fine, J.C., 1992. Greedy for groupers. Sea Frontiers, Nov-Dec. 1992, 68-71.

Gayanilo, F., Sparre, P., Pauly, D., 1996. FAO-ICLARM stock assessment tools. User's manual. FAO Comput. Inform. Ser. Fisheries 8, 126.

Gobert, B., 1990. Production relative des pêcheries côtières en Martinique. Aquat. Living Resour. 3(3), 181-191.

Gobert, B., 1991. Eléments d'évaluation de l'état des ressources en poissons du plateau insulaire martiniquais. Doc. sci. Pôle caraỉbe 31, 73.

Gobert, B., 1996. Approche historique de l'abondance et de l'exploitation des grandes espèces de Serranidae en Martinique. Proc. Gulf Carib. Fish. Inst. 44, 391-412.

Gobert, B., 2000. Comparative assessment of multispecies reef fish resources in the Lesser Antilles. Fish. Res. 44, 247-260. 
Kawaguchi, K., 1974. Handline and longline fishing operations for snapper and related species in the Caribbean and adjacent waters. Mar. Fish. Rev. 36(9), 8-31.

Kimmel, J. J., Appeldoorn, R. S., 1992. A Critical review of fisheries and fisheries management policy in Puerto-Rico. Proc. Gulf Carib. Fish. Inst. 41, 349-360.

Koslow, J. A., Aiken, K., Auil, S., Clementson, A., 1994. Catch and effort analysis of the reef fisheries of Jamaica and Belize. Fish. Bull. US 92, 737-747.

Luckhurst, B.E., 1996. Trends in commercial fishery landings of groupers and snappers in Bermuda from 1975 to 1992 and associated fishery management issues. ICLARM Conf. Proc. 48, 277288.

Manooch, C.S., 1987. Age and growth of snappers and groupers. In: Ralston S., Polovina, J.J. (Eds), Tropical snappers and groupers : biology and fisheries management. Westview Press, Boulder and London, pp. 329-374.

Marten, G.G., Polovina, J.J., 1982. A comparative study of fish yields from various tropical ecosystems. In: Pauly, D., Murphy, G.I. (Eds), Theory and Management of Tropical Fisheries. ICLARM/CSIRO, pp. 255-289.

Matos-Caraballo, D., 1997. Status of the groupers in Puerto-Rico, 1970-1995. Proc. Gulf Carib. Fish. Inst. 49, 340-353.

Mendoza, J.J., Larez, A., 1996. Abundance and distribution of snappers and groupers targeted by the artisanal medium-range fishery off Northern Venzuela. ICLARM Conf. Proc. 48, 266-276.

Munro, J.L., 1983. Caribbean coral reef fishery resources. ICLARM Stud. Rev. 7, 276.

Munro, J.L., 1984. Yields from coral reef fisheries. Fishbyte 2(3), 13-15.

Neilson, J.D., Aiken, K.A., Mahon, R., 1999. Potential yield estimates for reef and slope fisheries : a review of approaches and their limitations with special references to the Caribbean. Proc. Gulf Carib. Fish. Inst. 46, 360-376.

Parrish, J.D., 1987. The trophic biology of snappers and groupers. In: Ralston S., Polovina, J.J. (Eds), Tropical snappers and groupers : biology and fisheries management. Westview Press, Boulder and London, pp. 405-463.

Ralston, S., 1987. Mortality rates of snappers and groupers. In: Ralston S., Polovina, J.J. (Eds), Tropical snappers and groupers : biology and fisheries management. Westview Press, Boulder and London, pp. 375-404.

Reynal, L., Druault-Aubin, V., Lagin, A., Rivoalen, J.J., in press. Fishing on spawning aggregations sites of groupers in Martinique (mutton hamlet Alphestes afer). Proc. Gulf Carib. Fish. Inst. 55.

Russ G.R., 1991. Coral reef fisheries : effects and yields. In : Sale, P.F. (Ed.), The ecology of fishes on coral reefs. Acad. Press, San Diego, Calif., pp. 601-635.

Smith, G.B., 1988. Abundance and potential yield of groupers (Serranidae), snappers (Lutjanidae) and grunts (Haemulidae) on the Little and Great Bahama banks. 1988. FAO Fish. Rep. 376, 84-105.

\section{$\underline{\text { Tables }}$}

\begin{tabular}{|l|c|c|c|c|c|c|c|c|c|c|c|c|}
\hline Area & J & F & M & A & M & J & J & A & S & O & N & D \\
\hline Guanaja & 0 & 12 & 39 & 32 & 51 & 47 & 40 & 52 & 52 & 51 & 50 & 39 \\
\hline Santa Elena & 0 & 23 & 28 & 27 & 27 & 26 & 27 & 27 & 27 & 25 & 27 & 25 \\
\hline East Roatán & 0 & 10 & 3 & 16 & 23 & 22 & 18 & 18 & 9 & 26 & 38 & 33 \\
\hline West Roatán & 0 & 3 & 6 & 24 & 25 & 41 & 52 & 65 & 49 & 0 & 56 & 48 \\
\hline Utila & 16 & 18 & 89 & 66 & 57 & 59 & 62 & 70 & 75 & 75 & 41 & 35 \\
\hline
\end{tabular}

Table 1. Monthly number of boats monitored for the daily record of effort, gear and catch in 1999

\begin{tabular}{|l|c|c|c|c|}
\hline Area & \multicolumn{2}{|c|}{ Trips sampled } & \multicolumn{2}{c|}{ Fish measured } \\
\hline & 1999 & 2000 & 1999 & 2000 \\
\hline Utila & 311 & 302 & 11291 & 13624 \\
\hline West Roatán & 40 & 47 & 522 & 580 \\
\hline
\end{tabular}




\begin{tabular}{|l|c|c|c|c|}
\hline East Roatán & 115 & 62 & 2277 & 1219 \\
\hline Santa Elena & 63 & 49 & 857 & 683 \\
\hline Guanaja & 147 & 94 & 5563 & 3034 \\
\hline Total & 676 & 554 & 20510 & 19140 \\
\hline
\end{tabular}

Table 2. Number of trips sampled and of fish measured in 1999 and 2000

\begin{tabular}{|l|l|l|l|}
\hline Species & $\mathrm{L}_{\infty}$ & $\mathrm{K}$ & Size at first reproduction \\
\hline O. chrysurus & 53.4 & 0.20 & 25 \\
\hline L. analis & 85.0 & 0.15 & 40 (first spawning) - 55 (average maturation) \\
\hline L. synagris & 41.0 & 0.25 & 18 \\
\hline E. striatus & & & 50 (females) - 36-50 (sex reversal) \\
\hline M. venenosa & 86.0 & 0.15 & 50 (females) - 65 (sex reversal) \\
\hline E. fulvus & 37.0 & 0.30 & 16 (males) - 22 (females) \\
\hline E. guttatus & 50.0 & 0.20 & $16-20$ (males) - 20-30 (females) \\
\hline
\end{tabular}

Table 3. Biological parameters used for species-based analyses (lengths in $\mathrm{cm}$ )

\begin{tabular}{|l|c|c|c|c|c|}
\hline Area & $\begin{array}{c}\text { Number } \\
\text { of boats }\end{array}$ & $\begin{array}{c}\text { Boats/ } \mathrm{km}^{2} \\
\text { shelf }\end{array}$ & $\begin{array}{c}\text { Average boat } \\
\text { length }(\mathrm{m})\end{array}$ & $\begin{array}{c}\text { \% boats } \\
\text { without engine }\end{array}$ & $\begin{array}{c}\text { Average power } \\
\text { of engines (hp) }\end{array}$ \\
\hline Utila & 114 & - & 8.7 & 4.4 & 44.0 \\
\hline West Roatán & 79 & 1.58 & 5.7 & 46.8 & 26.9 \\
\hline East Roatán & 123 & 2.37 & 5.1 & 67.5 & 21.4 \\
\hline Santa Elena & 91 & 1.21 & 5.8 & 53.8 & 19.6 \\
\hline Guanaja & 111 & 0.53 & 5.9 & 36.9 & 25.8 \\
\hline
\end{tabular}

Table 4. Main characteristics of the fishing fleet in the Bay Islands in 1999

\begin{tabular}{|l|c|c|c|c|c|}
\hline Area & Handlines & Spearguns & Traps & Nets & Total \\
\hline Utila & 5990 & 498 & 17 & 33 & 6538 \\
\hline West Roatan & 6937 & 37 & 10 & & 6984 \\
\hline East Roatan & 4744 & 3964 & 162 & 72 & 8942 \\
\hline Santa Elena & 3197 & 3556 & 4 & 14 & 6771 \\
\hline Guanaja & 5680 & 2982 & 392 & 113 & 9167 \\
\hline Total & 26548 & 11037 & 585 & 232 & 38402 \\
\hline
\end{tabular}

Table 5. Overall (fish, lobster, conch) fishing activity by gear and area in 1999 (number of trips)

\begin{tabular}{|l|c|c|c|c|c|}
\hline & Utila & West Roatán & $\begin{array}{c}\text { East } \\
\text { Roatán }\end{array}$ & $\begin{array}{c}\text { Santa } \\
\text { Elena }\end{array}$ & Guanaja \\
\hline Shelf area 0-100 ${\mathrm{m}\left(\mathrm{km}^{2}\right)}^{2}$ & - & 50 & 52 & 75 & 211 \\
\hline Total fishing effort $(\mathrm{x} \mathrm{1000} \mathrm{hook-hr)}$ & 243.1 & 107.3 & 178.2 & 49.2 & 97.5 \\
\hline Relative fishing effort $(\mathrm{x} 1000$ hook-hr/km²) & & 2.15 & 3.43 & 0.66 & 0.46 \\
\hline Total catch (t) : & & & & & \\
\hline all snappers and groupers & 207.1 & 83.7 & 37.1 & 15.5 & 56.8 \\
\hline shallow-water snappers and groupers & 185.6 & 70.9 & 32.5 & 10.9 & 40.1 \\
\hline Relative catch $\left(\mathrm{kg} / \mathrm{km}^{2}\right)$ : & & & & & \\
\hline all snappers and groupers & - & 1674 & 713 & 206 & 269 \\
\hline shallow-water snappers and groupers & - & 1419 & 626 & 145 & 190 \\
\hline
\end{tabular}




\begin{tabular}{|c|c|c|c|c|c|}
\hline CPUE of the line fishery (kg / hook-hr) & & & & & \\
\hline all snappers and groupers & 0.855 & 0.781 & 0.216 & 0.311 & 0.563 \\
\hline shallow-water snappers and groupers & 0.765 & 0.662 & 0.171 & 0.205 & 0.387 \\
\hline
\end{tabular}

Table 6. Indicators for the snapper-grouper fishery by area in 1999

\begin{tabular}{|c|c|c|c|c|c|c|}
\hline Species & Gear & Utila & West Roatán & East Roatán & Santa Elena & Guanaja \\
\hline E. cruentatus & $\mathrm{L}$ & $\underline{\mathbf{2 6 . 5 0}}(3.55)$ & $\underline{17.93}(2.64)$ & $20.30(2.85)$ & $20.69(2.43)$ & $19.91(4.76)$ \\
\hline E. fulvus & $\mathrm{L}$ & $24.97(2.76)$ & - & $21.05(2.49)$ & $21.09(2.27)$ & $22.78(3.13)$ \\
\hline E. guttatus & $\mathrm{L}$ & $35.30(4.63)$ & $28.92(7.73)$ & $26.43(5.39)$ & $\underline{26.42}(7.80)$ & $29.41(6.13)$ \\
\hline E. guttatus & $\mathrm{S}$ & 40.30 (3.29) & - & $\underline{25.47}(6.18)$ & 33.91 (3.48) & - \\
\hline E. striatus & $\mathrm{S}$ & $51.54(6.79)$ & - & 36.55 (12.17) & $42.70(8.32)$ & - \\
\hline E. striatus & $\mathrm{T}$ & $\mathbf{6 1 . 1 4}(7.56)$ & - & - & - & $\underline{40.00}(6.87)$ \\
\hline L. analis & $\mathrm{L}$ & $\underline{\mathbf{4 0 . 5 9}}(9.11)$ & - & $31.04(8.90)$ & $34.64(7.43)$ & $35.35(9.75)$ \\
\hline L. apodus & $\mathrm{L}$ & $32.57(6.34)$ & $29.06(6.12)$ & $25.45(4.56)$ & $29.70(5.82)$ & $31.28(4.92)$ \\
\hline L. apodus & $\mathrm{S}$ & $\underline{30.73}(6.70)$ & - & $24.89(7.33)$ & - & - \\
\hline L. griseus & $\mathrm{L}$ & $\underline{\underline{\mathbf{2 8 . 1 6}}}(6.59)$ & - & $24.33(3.67)$ & - & $26.94(5.78)$ \\
\hline L. purpureus & $\mathrm{L}$ & $32.32(5.76)$ & - & $24.50(7.26)$ & - & - \\
\hline L. synagris & $\mathrm{L}$ & $24.47(4.23)$ & $23.04(2.89)$ & $20.28(2.96)$ & $21.14(2.82)$ & $20.52(3.24)$ \\
\hline L. synagris & $\mathrm{T}$ & $\underline{\mathbf{2 2 . 2 0}}(2.98)$ & - & - & - & $\underline{22.08(3.10)}$ \\
\hline M. venenosa & $S$ & $52.80(11.77)$ & - & $42.07(13.46)$ & - & - \\
\hline O. chrysurus & $\mathrm{L}$ & $28.87(5.25)$ & $\underline{\underline{29.73}(6.49)}$ & $\underline{25.43}(7.25)$ & $27.77(5.11)$ & $27.07(6.78)$ \\
\hline
\end{tabular}

Table 7. Means and standard deviations of length-ferquency samples (data from 1999 and 2000 pooled). For each species, the highest mean is in bold underlined, and the lowest in italics underlined ; only samples of more than 10 fish for the whole period were considered. Gears : handlines (L), spearfishing $(\mathrm{S})$, trammelnets $(\mathrm{T})$.

\begin{tabular}{|l|c|c|c|c|}
\hline Area & $\begin{array}{c}\% \\
\mathrm{p}>0.05\end{array}$ & $\begin{array}{c}\% \\
\mathrm{p}<0.01\end{array}$ & $\begin{array}{c}\% \\
\text { higher mean }\end{array}$ & $\begin{array}{c}\text { Number } \\
\text { of tests }\end{array}$ \\
\hline Utila & 10,8 & 89,2 & 97,3 & 37 \\
\hline West Roatán & 25,0 & 65,0 & 50,0 & 20 \\
\hline East Roatán & 28,6 & 65,7 & 8,6 & 35 \\
\hline Santa Elena & 46,7 & 43,3 & 43,3 & 30 \\
\hline Guanaja & 43,3 & 46,7 & 46,7 & 30 \\
\hline
\end{tabular}

Table 8. Summary of t-tests conducted on differences of mean length between each of the areas and all the other ones. 


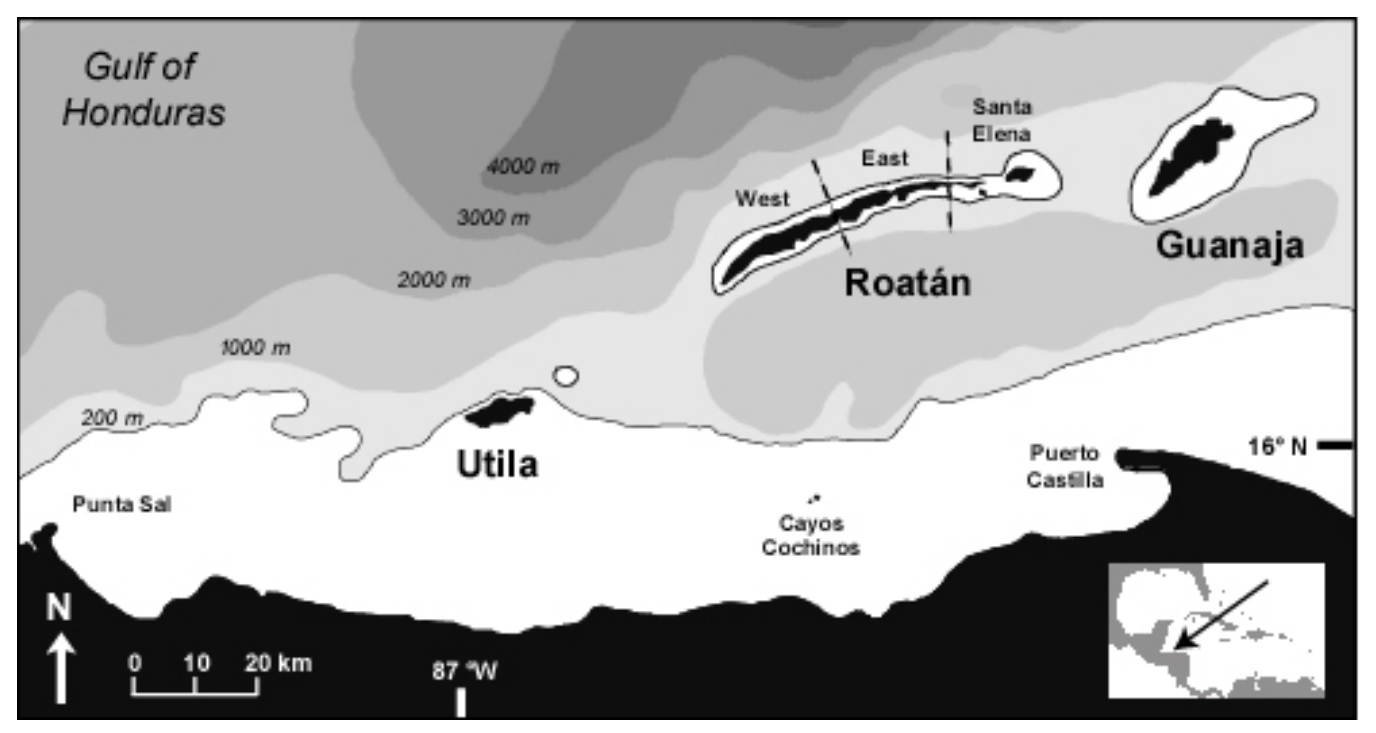

Figure 1. Map of the area

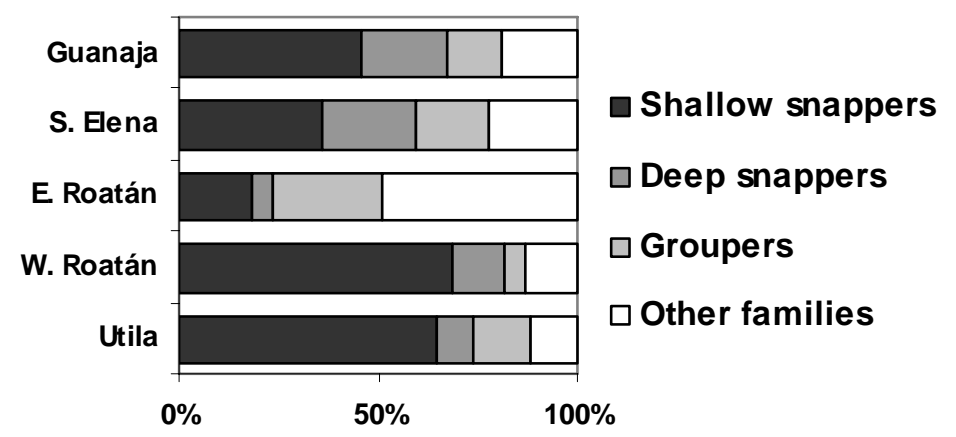

Figure 2. Proportion of shallow snappers, deep snappers, groupers, and other families in the demersal fish catch in 1999.

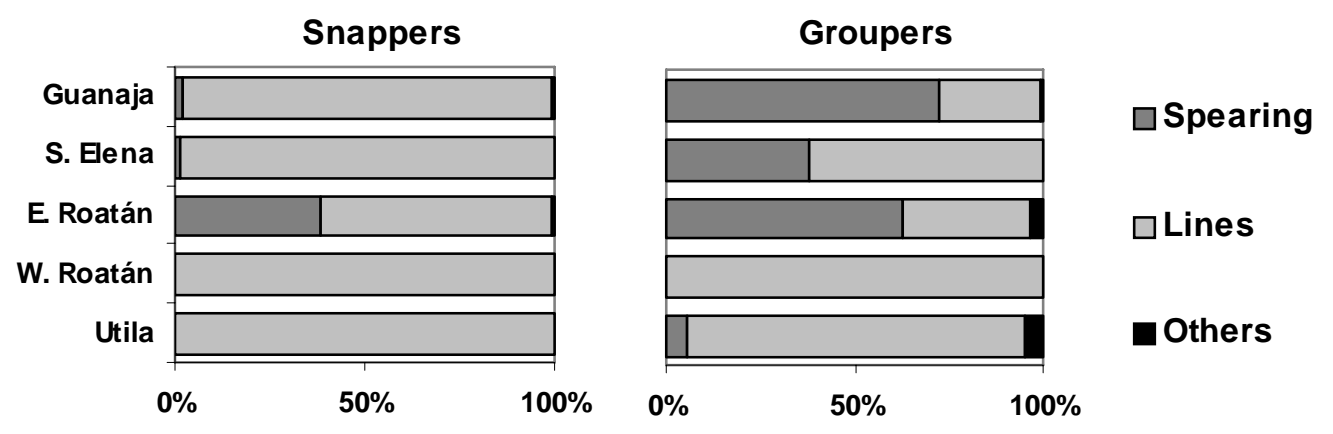

Figure 3. Relative contribution of the gears in the catch of the shallow-water snappers and groupers in 1999. 


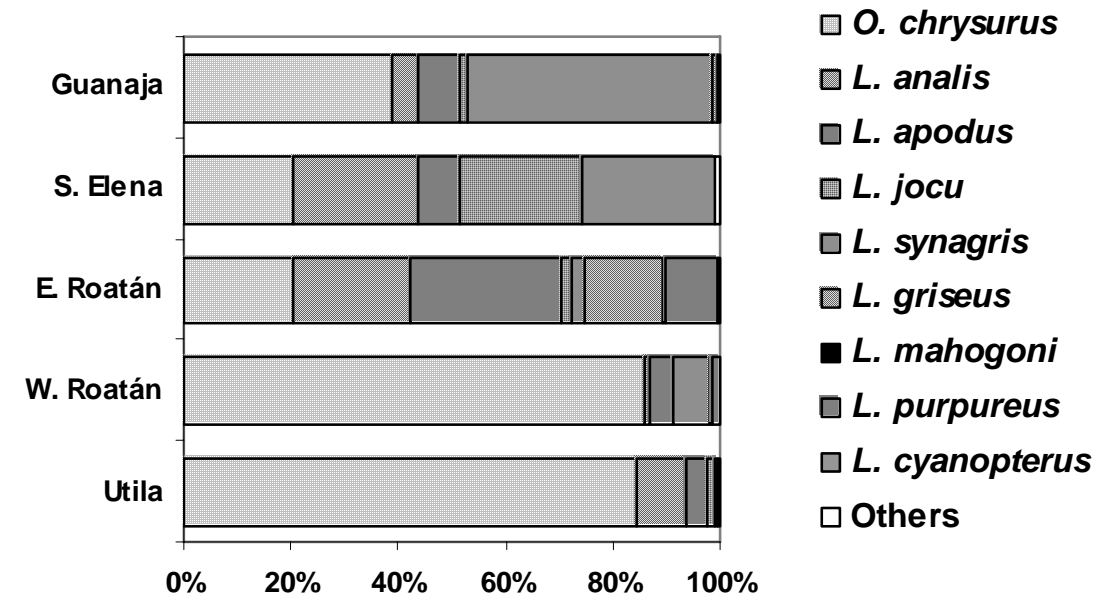

Figure 4. Percent catch composition of shallow-water snappers in 1999.

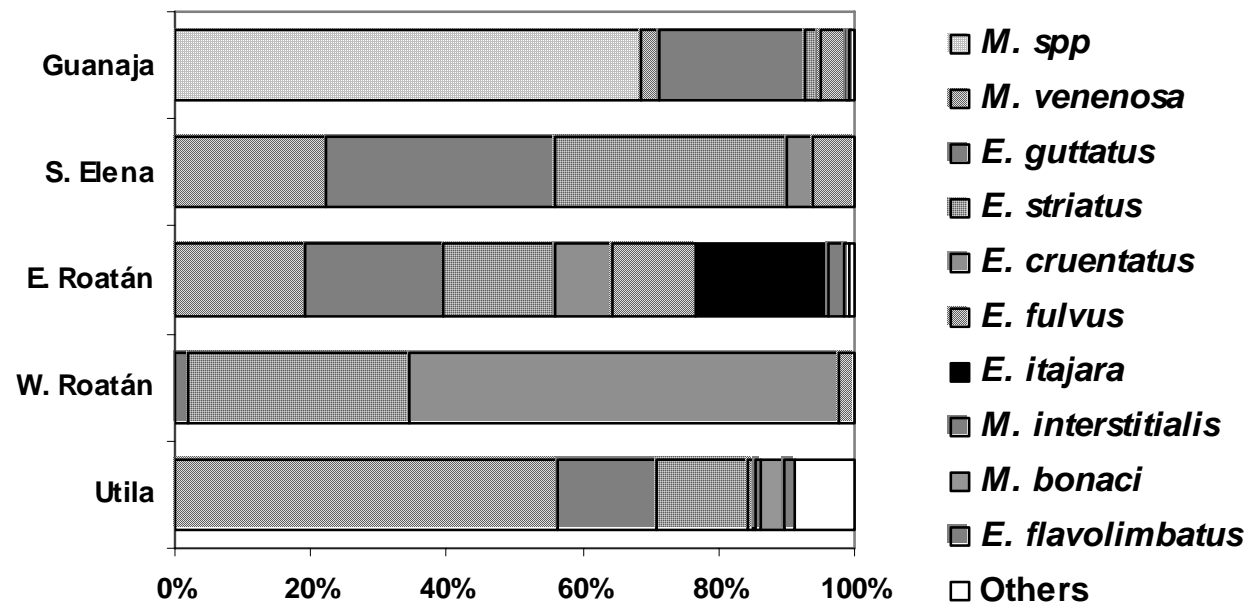

Figure 5. Percent catch composition of groupers in 1999. 


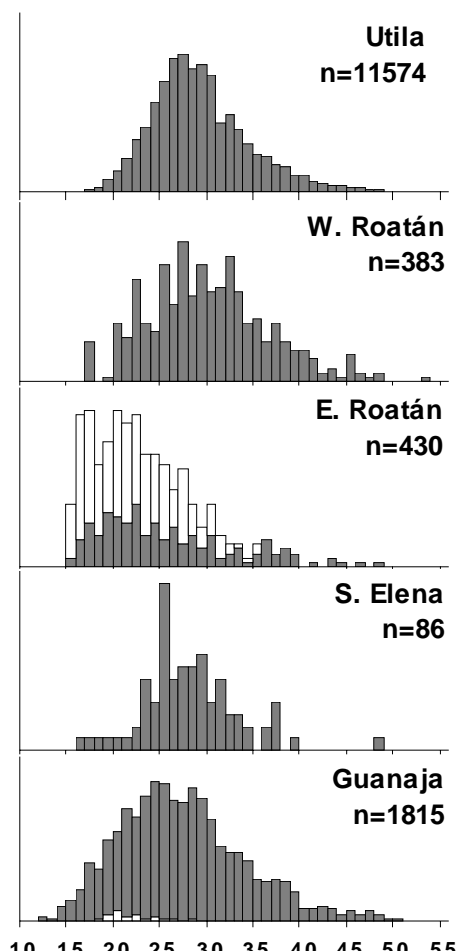

Ocyurus chrysurus

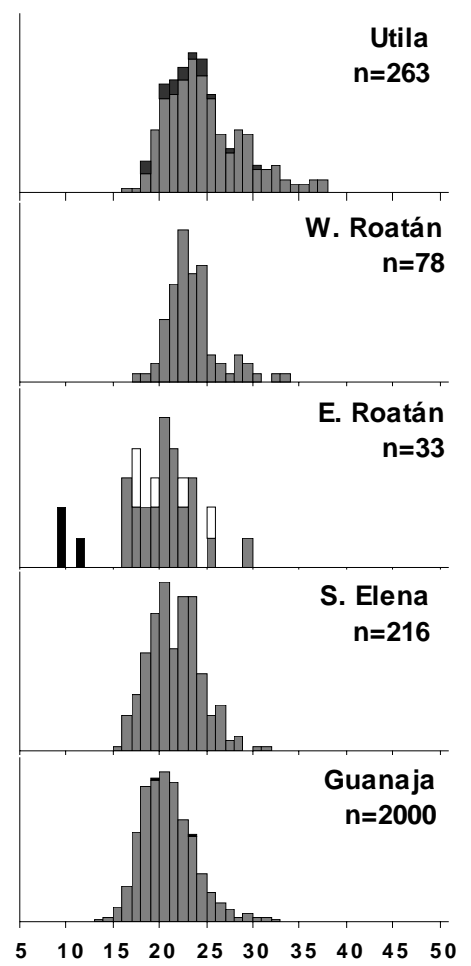

Lutjanus synagris
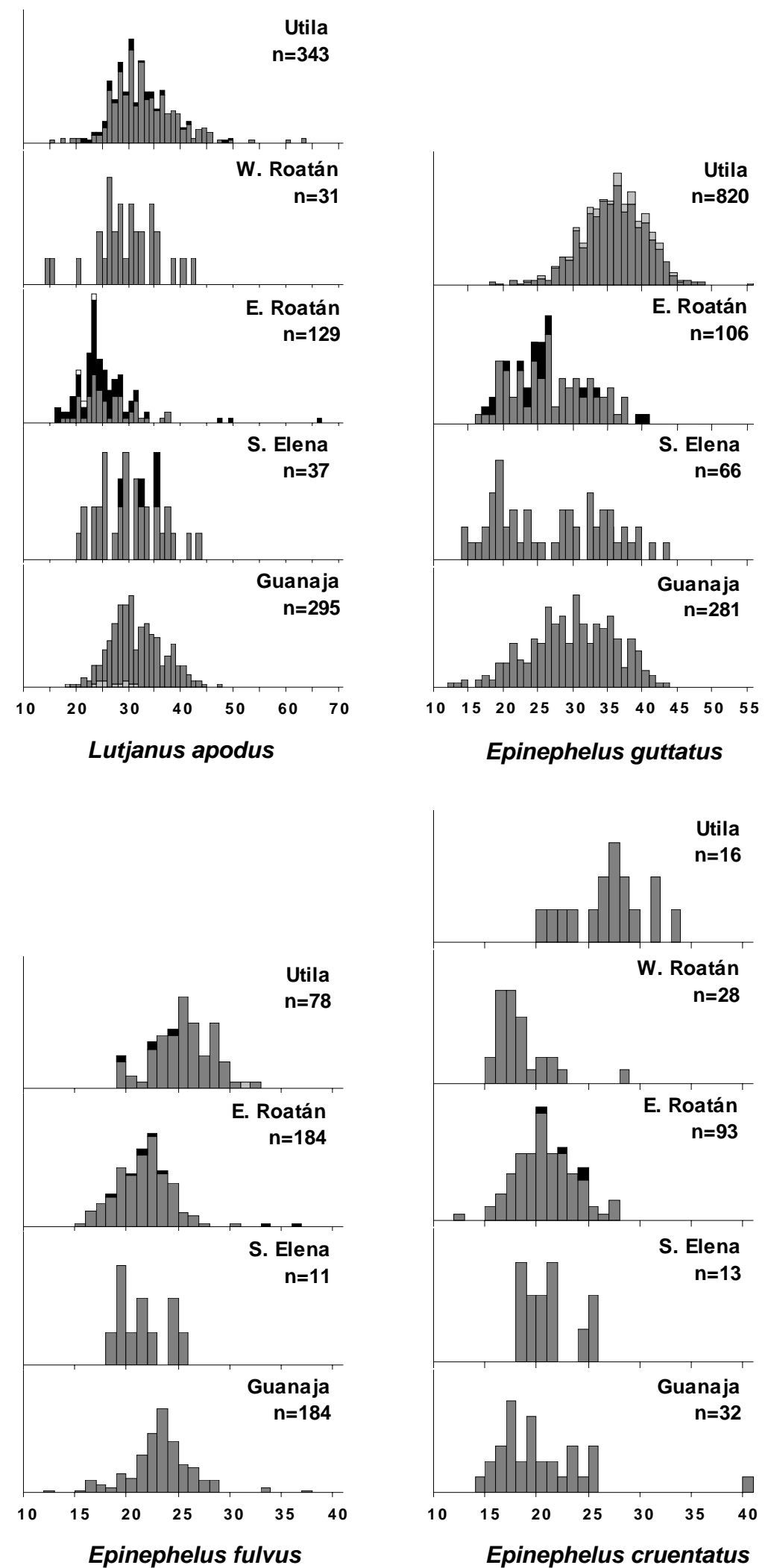


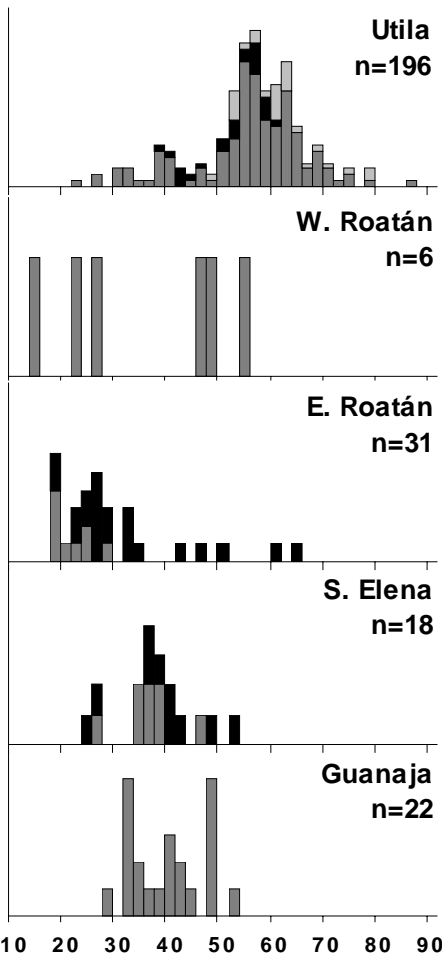

Epinephelus striatus
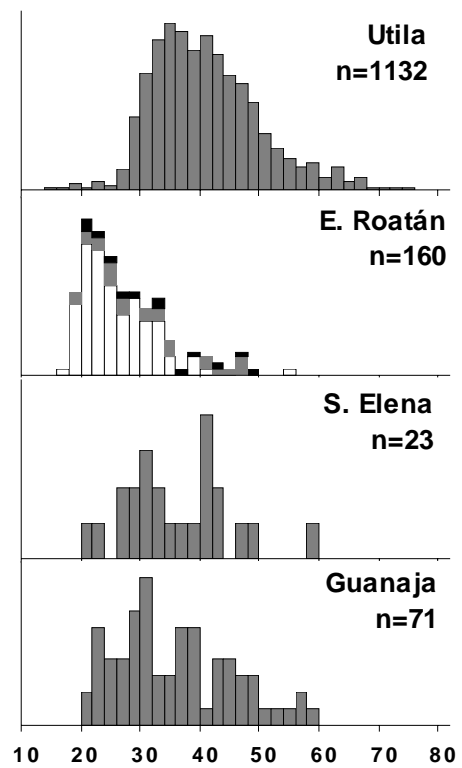

Lutjanus analis

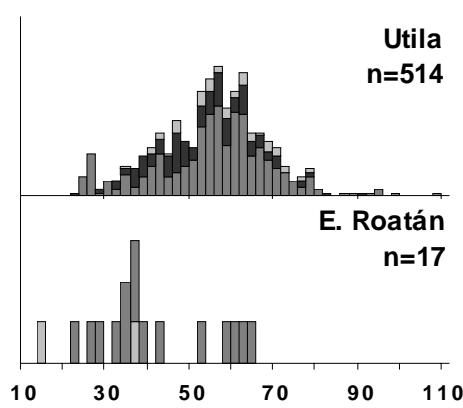

Mycteroperca venenosa

Figure 6. Size structure of the catch of shallow-water snappers and groupers (sample sizes do not necessarily reflect the contribution of the gears in the catch). Black : spearguns, dark grey : handlines, light grey : traps, white : nets.

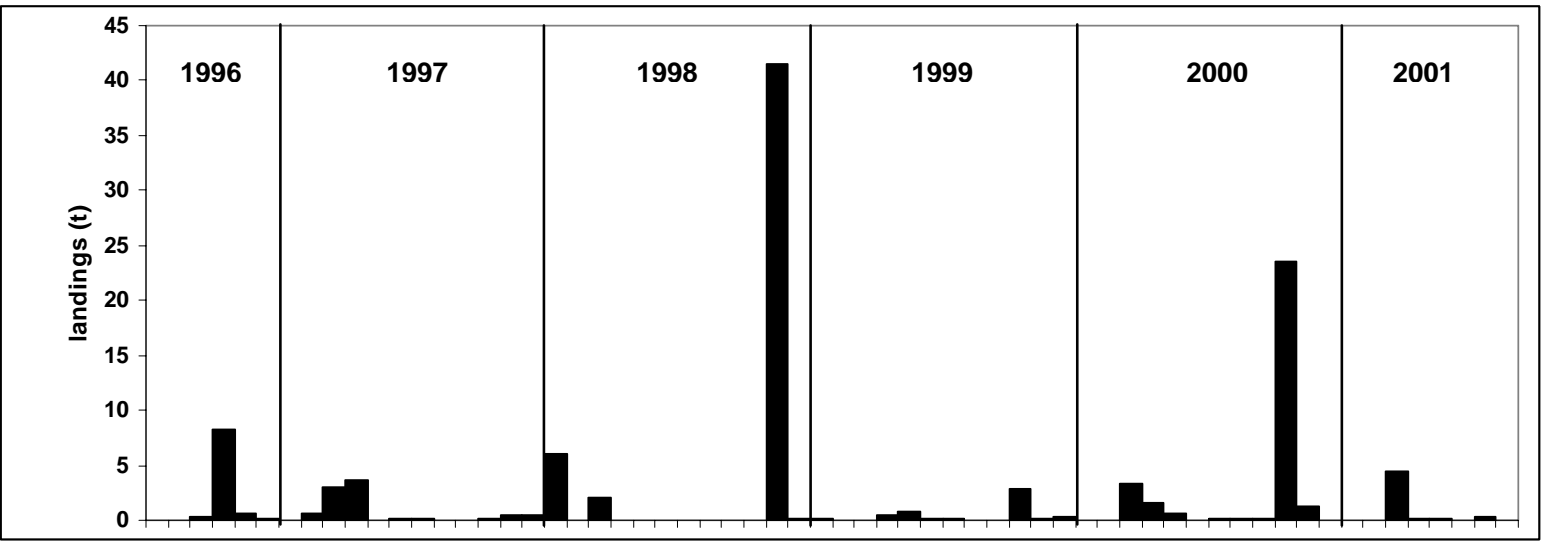

Figure 7. Monthly quantities of mutton snapper L. analis bought from the artisanal fishermen by the main fish export firm of Utila from July 1996 to August 2001 (in grey : no data from April to October 1998). 